\title{
TYPE DESIGNATIONS AND SYNONYMIES FOR NORTH AMERICAN SILPHIDAE (COLEOPTERA)
}

\author{
By Stewart B. PecK ${ }^{1}$ and Scott E. Miller ${ }^{2}$
}

The purpose of this paper is to provide type data and lectotype and neotype designations for North American Silphidae described by J. L. LeConte, Thomas Say, M. H. Hatch, and J. W. Angell, and new synonymies of other species. We are engaged in ongoing revisionary work on North American silphids (e.g. Miller and Peck, 1979) and have found considerable nomenclatural confusion because of varying interpretations of poor descriptions and names not fixed to types. Publication of these data is also necessary for their inclusion in the forthcoming fascicle on this family in "A Catalog of the Coleoptera of America North of Mexico", U.S. Dept. Agric. Handbook 529 (J. M. Kingsolver, editor-in-chief). Improved identification keys and characterizations of all United States and Canadian silphids are given in Peck (1982a).

In the LeConte and Horn collections of the Museum of Comparative Zoology (MCZ), Harvard University, the specimens that bear "type" labels have not been formally validated, and these were placed on the assumed types (supposedly the first in each series) during routine curation early in this century. The Say neotypes were selected from the LeConte collection because it is generally agreed that the original Say material is lost, and that LeConte had the opportunity to compare his specimens with those in Say's collection (see Lindroth and Freitag, 1969; Miller and Peck, 1979). The specimens designated do not differ in characters from the original published descriptions.

Primary types from the Hatch collection have been deposited by Oregon State University in the United States National Museum of Natural History (USNM).

Types have recently been designated for Silpha aenescens Casey, Silpha ramosa Say, Agyrtes longulus LeConte, and Necrophilus pettitii Horn (Miller and Peck, 1979; Peck, 1974 and 1982b).

'Department of Biology, Carleton University, Ottawa, Ontario, Canada K IS 5B6. ${ }^{2}$ Museum of Comparative Zoology, Harvard University, Cambridge, Massachusetts 02138 . 
Herman (1964) has shown that the correct spelling of the genus of the sexton or burying beetles is Nicrophorus Fabricius, 1775, and not Necrophorus Thunberg, 1789 (see Madge, 1980).

\section{Type Specimens of Nominal Species}

Necrophorus lunatus LeConte 1853: 277. LECTOTYPE (here designated), a male with a yellow disc and a red square label with white dorsal margin "Type 3144" and white label "N. sayi Lap/lunatus Lec.," and our designation label, in MCZ. The yellow circle in LeConte's code is supposed to mean "Central Valley or Western States (Ohio, Illinois, Indiana, Missouri, Western Tennessee, Kentucky, Iowa, and southern Great Lakes)". However, the species localities were published by LeConte as New York and Georgia. The name is a junior synonym of Nicrophorus sayi Laporte, 1840; and a junior homonym of Nicrophorus lunatus Fischer, 1842, of Eurasia. Harold (1868) supplied Necrophorus luniger as a replacement name for Necrophorus lunatus LeConte.

Necrophorus confossor LeConte 1854: 20. Described from a single specimen, the HOLOTYPE: a male with a dark blue disc (indicating Oregon and Washington), and a red square label with white dorsal margin "Type 3146" and white label "N. confossor/ Cooper Lec.", and white label "maratimus 4", in MCZ. The published type locality is Prairie Paso, which is in Washington. The species is a synonym of Nicrophorus investigator Zetterstedt, 1824.

Necrophorus pollinctor LeConte 1854: 19. LECTOTYPE (here designated) a male with dark blue disc (meaning Oregon and Washington), red label with white dorsal margin "Type 3145", white label "N. pollinctor/Cooper Lec.", white label "vespilloides 9", and our designation label, in MCZ. Accompanied by male paralectotype with blue disc, red label with white dorsal margin "Type $/ 2 / 3145$ " and white label "vespilloides 10" and male paralectotype with blue disc and red label with white dorsal margin "Type/2/3145" and white label "vespilloides 11", both in MCZ. The published distribution is from Fort Vancouver to the Yokolt Plain. The species is a synonym of Nicrophorus defodiens Mannerheim, 1846, and a junior homonym of Necrophorus pollinctor Mannerheim, 1853 (which is a synonym of Necrophorus investigator Zetterstedt, 1824). 
Necrophorus orbicollis Say 1825: 177. NEOTYPE (here designated), a male in LeConte collection with white label "N. orbicollis/Say/ Hallii Kirby", and our designation label, in MCZ. Published localities are from "the N.W. Territory" (which at the time meant Ohio, Indiana, Illinois, Wisconsin, and Michigan), and "very rare in the Middle States", and "one specimen from Dr. T. W. Harris of Milton, Massachusetts". The Harris collection is preserved in the $\mathrm{MCZ}$ and was examined but no specimens of the species were found that would help to validate Say's species concept.

Nicrophorus hecate immaculosis Hatch 1957: 15. The name was validated by this use as a subspecies, not by its earlier use as an aberration (Hatch 1927: 362) according to Article 10b of the ICZN. The holotype, which we have not seen, is a specimen from "California" in the Institut für Pflanzenschutzforschung Zweigstelle Eberswalde, East Berlin (formerly Deutsches Entomologisches Institut). Our examination of much west coast material (and unpublished data of R.S. Anderson) shows that immaculosis represents part of a range of variation in elytral patterning within $N$. hecate Bland 1865 , and, furthermore, that hecate represents a portion of variation within $N$. guttula Motschoulsky 1845 . We therefore propose immaculosis as a NEW SYNONYM of hecate, and hecate as a NEW SYNONYM of guttula.

Necrophorus maritimus Eschscholtz, in Guerin-Meneville 1835, Iconographie, plate 17, fig. 8. This name was last used by Hatch (1957: 14) as Necrophorus investigator maritimus, for material mostly from coastal islands of British Columbia with reduced elytral fascia. It was originally described from Sitcha Island, Alaska, but we have not seen authentic type material. Our examination (and unpublished data of R. S. Anderson) of much west coast material shows this to be one part of variation, which is not geographically coherent, of $N$. investigator Zetterstedt 1824, and we therefore propose maritimus as a NEW SYNONYM.

Necrophorus grandior Angell 1912: 307. LECTOTYPE (here designated), a male with labels "California", "Janson", "Original/ type", "Necrophorus / grandior / Angell", "Necrophorus / grandior / 2917 Ang./Det. M. H. Hatch 1925", "Necrophorus/germanicus/ ab. bipunctatus / ठ Kr./M. H. Hatch-1926" and our designation label, in USNM. Hatch (1927) cited this as the "type" (holotype), but it was published as a syntype. The species is a synonym of Nicro- 
phorus germanicus (Linnaeus), 1758. The location of the second syntype, a specimen of $N$. humator (Gleditsch) 1767 (according to Hatch 1927) is unknown. It is not in the Hatch collection at Oregon State University (G. L. Peters, pers. comm.).

Silpha truncata Say 1823: 193. NEOTYPE (here designated), a male with dark green disc (meaning New Mexico) and white label "S. truncata Say.", and our designation label, in MCZ. The published locality is "Arkansa" and "near the Rocky Mountains", which we take to mean the upper reaches of the Arkansas River in eastern Colorado. Say collected the single specimen while he was a naturalist on Major Long's 1819 party exploring the upper reaches of the Platte, Arkansas, Canadian, and Red Rivers, of the southern Great Plains and foothills of the Rockies (Weiss and Ziegler, 1931). The species is now Thanatophilus truncatus (Say). Silpha bituberosa LeConte 1859b: 6. Described from a single specimen, the HOLOTYPE: a female with pale green disc (meaning Nebraska, Kansas, North Dakota, South Dakota, Oklahoma, Colorado, Wyoming, and Montana), and red label with white dorsal margin "Type 8952" and white label "S. bituberosa/ Drexler Lec.", in MCZ. The published type locality is "near Fort Bridger", now in SW Wyoming. The species is now in the genus Aclypea (in some literature as Blitophaga), but the former name is given priority, following Seidlitz (1888: 311$)$ as the first reviser in accordance with article 24 (a) (i) of the International Code of Zoological Nomenclature.

Silpha caudata Say 1823: 192. The species was described from material collected by Thomas Nuttall "on the upper Missouri" River and by Say from "near the Rocky Mountains." LeConte (1859c) recognized this species as a synonym of Silpha lapponica Herbst, now Thanatophilus lapponicus (Herbst), and this has been accepted ever since. We do not designate a neotype for this name, for it is not necessary in the interests of stability of nomenclature. Necrophilus tenuicornis LeConte 1859a: 84. Described from a single specimen, the HOLOTYPE: a female with dark blue disc (meaning Oregon and Washington), and red label with white dorsal margin "Type 3147" and white label "N. tenuicornis/P. Sound Lec." and white label "Pt./tenuicorne/(Lec)". in MCZ. The published type locality is Puget Sound, Washington. The species is now Apteroloma tenuicorne (LeConte). 


\section{New Subgeneric SyNONYMY}

Our studies, as well as those of R. S. Anderson, R. B. Madge, and A. F. Newton (all unpublished), have not provided data to support retention of the monotypic subgenus Necrocharis Portevin 1923 for Nicrophorus carolinus (Linnaeus 1771). Therefore we consider Necrocharis a NEW SYNONYM of Nicrophorus Fabricius 1775.

\section{ACKNOWLEDGEMENTS}

We thank A. F. Newton (MCZ), T. J. Spilman (USDA c/o USNM), M. D. Schwartz and G. L. Peters (both Oregon State University) for their courtesy in allowing study of specimens under their care. A. F. Newton and R. B. Madge reviewed the manuscript and have provided much helpful advice throughout our silphid studies. R. S. Anderson (and his unpublished Masters thesis at Carleton University on distribution and biology of Silphidae in Canada and Alaska) helped clarify questions of species identities. Miller's work was done while at the Santa Barbara Museum of Natural History and the Smithsonian Institution.

\section{Literature Cited}

ANGell, J. W.

1912. Two new North American species of Necrophorus (Coleop.). Ent. News, 23: 307.

Guerin-Meneville, M. F. E.

1835. Iconographie du Regne Animal de G. Cuvier. Insects. vol. 7. Bailliere, Paris. 576 pp, 104 plates. (plate 17 dated January, 1835 by Cowan, 1971, J. Soc. Bibliog. Natur. Hist., 6: 18-29: text dates to 1844).

HАTCH, M. H.

1927. Studies on the Silphinae. J. New York Ent. Soc., 35: 331-371.

1957. The beetles of the Pacific Northwest. Part II: Staphyliniformia. Univ. Washington Publ. Biol., 16. 384 pp. Univ. Washington Press, Seattle.

Herman, L. H., JR.

1964. Nomenclatural consideration of Nicrophorus (Coleoptera: Silphidae). Coleop. Bull., 18: 5-6.

LeConte, J. L.

1853. Synopsis of the Silphales of America, north of Mexico. Proc. Acad. Nat. Sci., Philadelphia, 6: 274-267.

1854. Descriptions of some new Coleoptera from Oregon, collected by Dr. J. G. Cooper of the North Pacific R.R. Expedition, under Gov. J.J. Stevens. Proc. Acad. Nat. Sci., Philadelphia, 7: 16-20.

1859a. Catalogue of the Coleoptera of Fort Tejon, California. Proc. Acad. Nat. Sci., Philadelphia, 1859: 69-90. 
1859b. The Coleoptera of Kansas and eastern New Mexico. Smithsonian Cont. to Knowledge, 11(6): 1-66, 3 plates.

1859c. The complete writings of Thomas Say on the entomology of North America. S.E. Cassino and Co., Boston. Two volumes, XXIV + 412 pp. +54 plates and IV $+814 \mathrm{pp}$.

Lindroth, C. H. AND R. Freitag

1969. North American ground-beetles (Coleoptera, Carabidae, excluding Cicindelinae) described by Thomas Say: designation of Lectotypes and Neotypes. Psyche, 76: 326-359.

MADGE, R. B.

1980. A catalogue of type-species in the family Silphidae (Coleoptera). Ent. Scand., 11: 353-362.

Miller, S. E. AND S. B. PeCK

1979. Fossil carrion beetles of Pleistocene California asphalt deposits, with a synopsis of Holocene California Silphidae (Insecta: Coleoptera: Silphidae). Trans. San Diego Soc. Nat. Hist., 19: 85-106.

PECK, S. B.

1974. A review of the Agyrtes (Silphidae) of North America. Psyche, 81: 501-506.

1982a. Silphidae and the associated families Agyrtidae and Leiodidae, in D. Dindal, ed., Soil Biology Guide. Wiley and Sons, in press.

1982b. Distribution and biology of flightless carrion beetle Necrophilus pettitii in eastern North America (Coleoptera; Silphidae). Ent. News, 92: $181-185$.

SAY, T.

1823. Descriptions of Coleopterous insects collected in the late expedition to the Rocky Mountains, performed by order of Mr. Calhoun, Secretary of War, under the command of Major Long. Jour. Acad. Nat. Sci., Philadelphia, 3: 139-216.

1825. Descriptions of new species of Coleopterous insects inhabiting the United States. Jour. Acad. Nat. Sci., Philadelphia, 5: 160-202.

SeIDlitz, G.

1887-1891. Fauna Baltica. Die Käfer (Coleoptera) der Deutschen Ostseeprovinzen Russlands. Zweite neu bearbeitete Auflage. Konigsberg: Hartungsch Verlagsdruckerei. (Silphidae issued in 1888)

WeIsS, H. B. AND G. M. ZEIGLER

1931. Thomas Say, Early American Naturalist. Charles C. Thomas Pub., Springfield, Ill. 260 pp. 

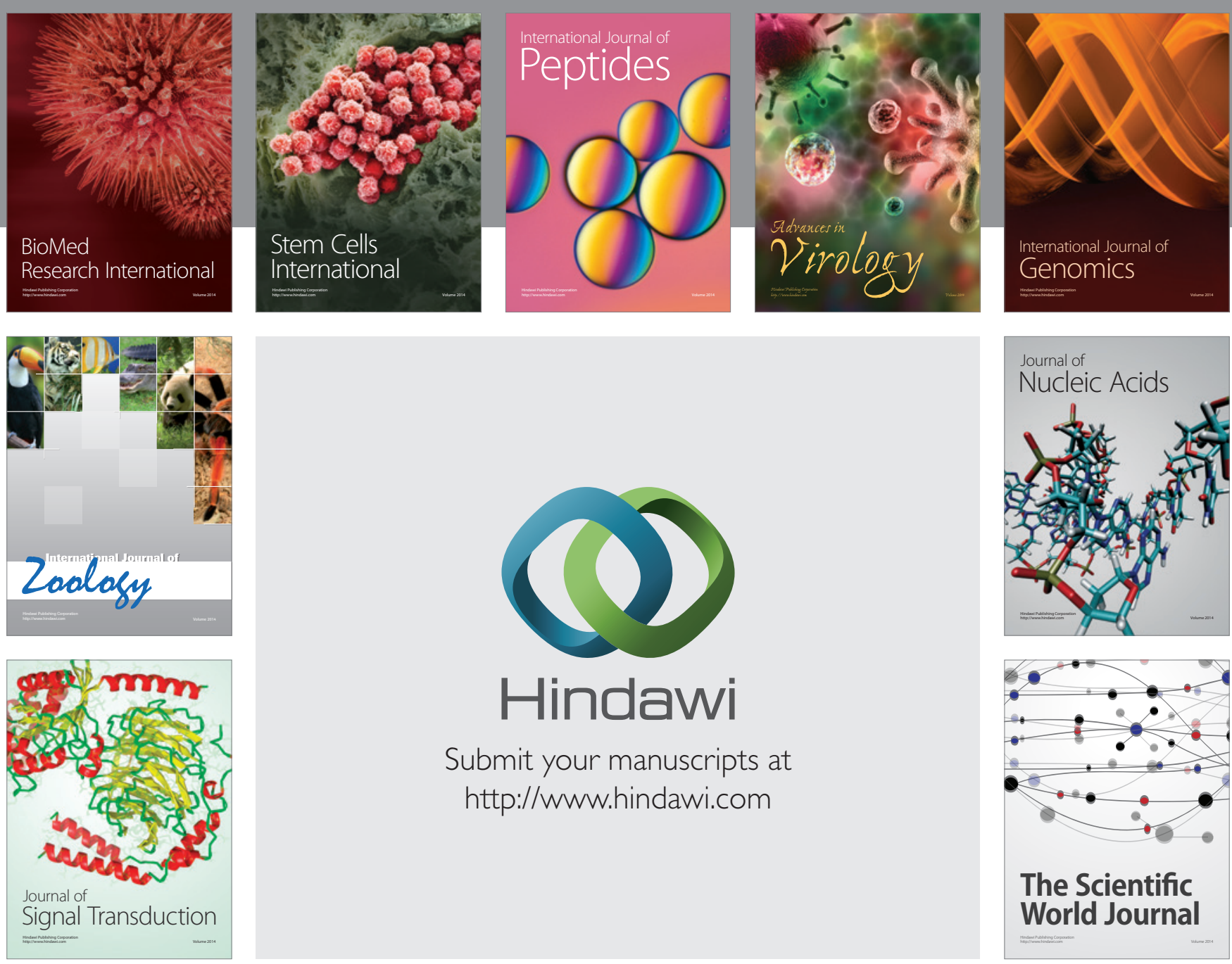

Submit your manuscripts at

http://www.hindawi.com
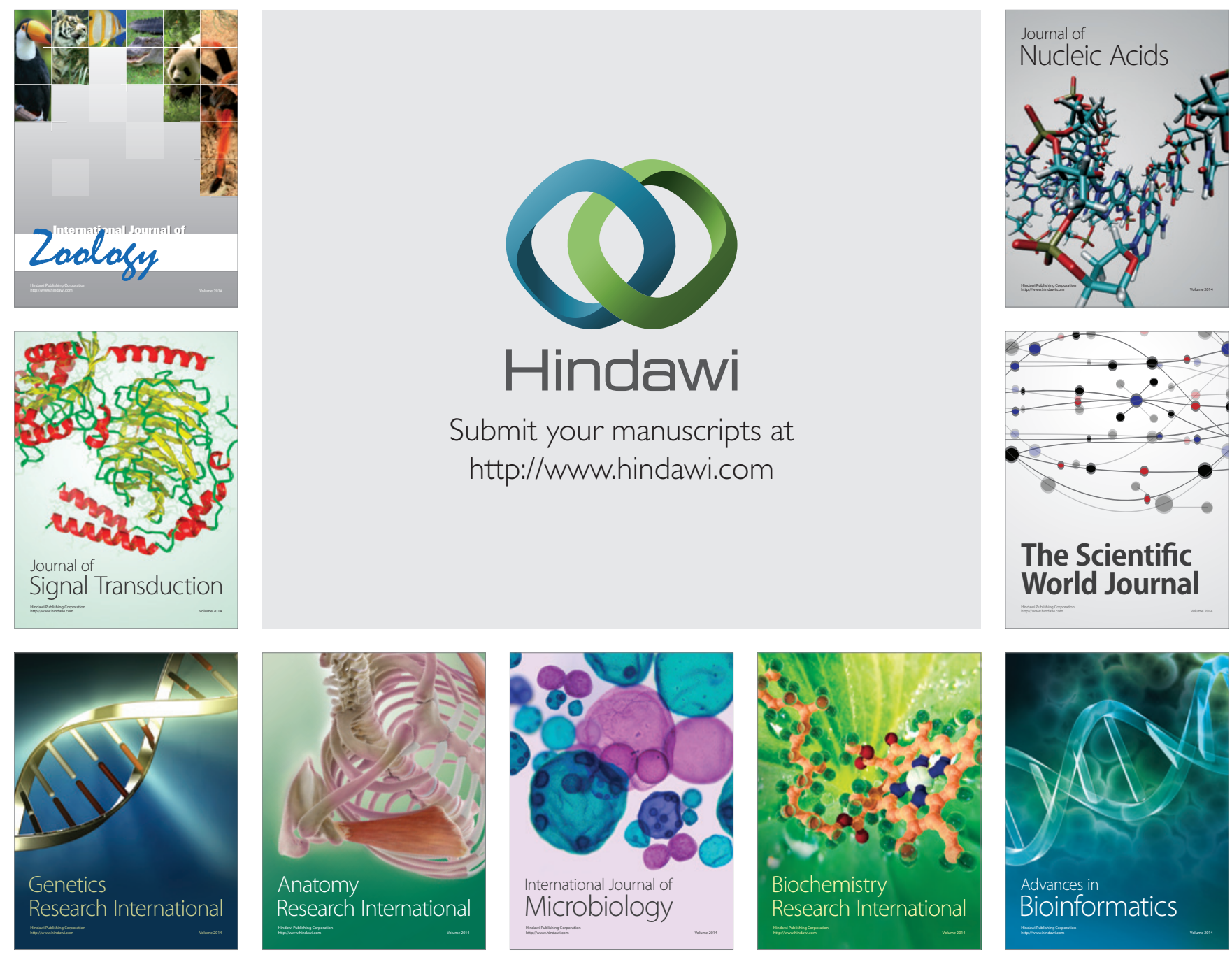

The Scientific World Journal
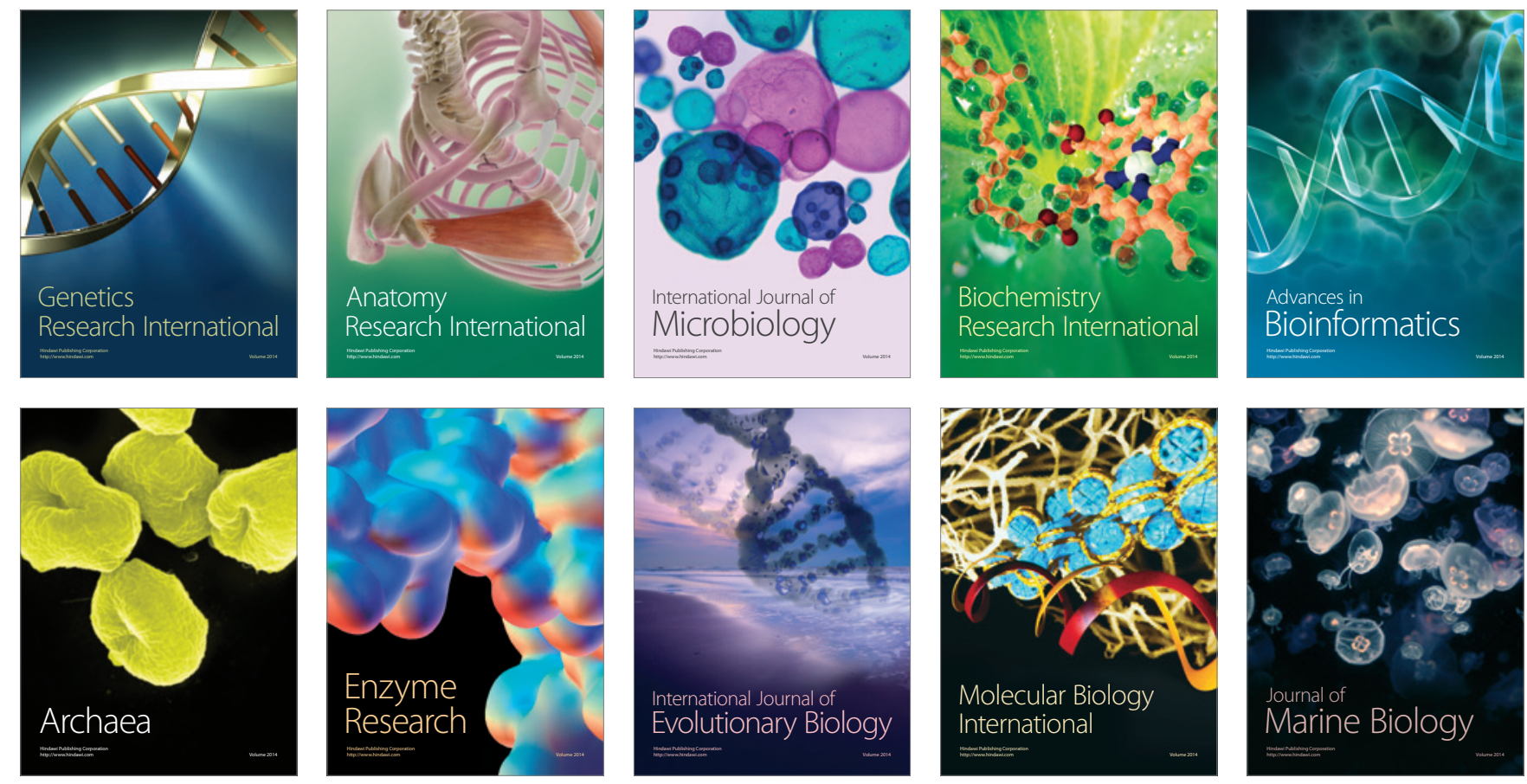